\title{
Strategic Management of Rural Community Empowerment: Based Local Resources
}

\author{
Imam Santosa \\ Lecturer of Department of Sociology, Faculty of Social and Political Sciences, \\ Jenderal Soedirman University \\ E-mail : Scokronegoro@yahoo.com; imamsantosa@unsoed.co.id
}

\begin{abstract}
The real meaning of empowerment of rural communities can be understood as a process of increasing the capacity utilization of the autonomy of every individuals for utilizing local resources in a productive and creative way in the rural community. Every community development efforts based on local resources need to be oriented to favor the interests of poverty alleviation in various typologies of rural areas. The empowerment of rural communities which are pro poor and sustainable requires systematic planning in order to avoid the effects of culture shock. This study aims to formulate management strategiesof community empowerment based on local resources. This study showed that strategic management empowerment of rural communities have strong links with policy makers in regulating the ability of the balance principle of natural resources and human resources synergistically. Culture shock can be reduced in a planned manner through social adjustments between the problems and the real needs of the poor in the rural development program goals and objectives. Evaluation and monitoring objective and are required to determine the achievement of goals and predict the chances of a culture shock as early as possible. The partnership and mutual trust among various parties have contributed to the empowerment pro-poor. Beside economic improvement, it can be showed that social cohesiveness can be better and culture shocks are able to be reduced. Pro poor development activities based on local resources must be integrated and minimizing cultural schock. Nevertheless, the implementation of strategic management require systematic steps to all aspects and accommodate social, cultural, political and technological interests.
\end{abstract}

Keywords : strategic management, empowerment, rural society, pro poor and local resources

\section{Introduction}

From those many concepts of community empowerment, there is one key concept that is fundamental and important. That one is the independence. Existence of independency in the community focused on the ability to perform autonomous decision making in a variety of interests based on ownership of local resources. The independence arises from the social climate of continuous learning (Friedmann, 1992). One group of people today requires various forms of local resource-based empowerment is people who live in rural areas.

The strategic goal of empowering rural communities include members belonging to weak citizens of the economic, social, cultural and political. However, a weak group of villagers who still has the potential to emerge from underdevelopment, illiterate, and poverty. The weak in rural pursue diverse livelihood patterns such as agricultural laborers, small traders, craftsmen micro industries, construction workers, ranchers and farmers traditional freshwater fish, unemployed, school dropouts and others. Determination of the poor who will also be activated in a variety of community empowerment in rural areas needs to be done carefully.

Empowerment is not an instant process, but a process of transformation that requires a series of steps that social change does not deviate from the original purpose (Wrihatnolo and Dwijowiyoto, 2002). Step of the earliest and fundamental conducted in each village community empowerment based on local resources are identified in detail the root of the problem that led to the problem of poverty. There are at least three categories of root causes of poverty in rural areas :

(1) instability use of natural resources, ( 2 ) 
economic necessity and ( 3 ) the lack of human resources quality. As a result of this pressure, social transformation can't walk faster and conversely poverty and its derivations are not easy to be controlled.

Low progression of empowerment of rural communities is also inseparable from the question of national development approaches that tend to be oriented of economy and technology. We understand this will remember the position of the people are in a transitional phase, especially democracy and globalization which have great impact on the continuity of the various dimensions of community life, including in rural areas. Such conditions often lead towards the empowerment of the "excessive" and as manifest as the euphoria of democracy which refract meaning rural community development goals. Penetration of democracy, globalization and markets that hit the village social structure where the poor and choke increasingly powerless to develop your own potential as a human being productive, creative and competitive.

Their resources continue to slowly diminish as fertile agricultural land sold to investors who develops a wide range of commercial businesses in the countryside. In addition, many community development programs have not been in accordance with the conditions and problems of the real target audience because the approach is top down. As a consequence, the range of programs itself can not touch all of the interests of rural society (Santosa, 2009). This is compounded by the "political weight " and the cost of access to information that is costly innovation (Santosa, 2009). This issue is not worth a row allowed to continue as prone to cause serious problems.One solution which is urgent and crucial to do is how to develop a strategic management model for the empowerment of rural communities based on local resources. The important thing about the formulation of the strategic management later can be functioned as a valuable consideration for policy makers in managing the rural community empowerment. This policy consider harmony between the use of natural resources and human resources.

\section{Analysis And Discussion}

According to data presented by Central Bereau of Statistics in 2013, it is known that sum of poor people in Indonesia reached 28.07 million (11 percent). Distribution of the number of the poor in the countryside in 2013 amounted 17.74 million more than in urban areas which are only 10.33 million. In the colonial era, the colonial goverment launched "ethical politics" or political reciprocation which are treated to the inlander. The second period, during the program launched by "Old Order" Bung Karno gave "Desa Makmur" Program. Then on the third time that New Order announced a program known from Pelita I to VI : Program Guidance and Mass Intensification (Inmas), UPPKS (Family Planning Board), cooperatives, fair and at the end of Year of Pelita VI launched IDT (Inpres Desa Tertinggal), Social Security Program and other. Form of empowerment in the third period of the Reformation Era continued today with the Rice Program Poor, Bantuan Langsung Tunai (BLT) or Direct Cash Assistance, ASKESKIN (Asuransi Kesehatan Bagi Penduduk Miskin) or Health Insurance For The Poor, Program Nasional Pembangunan Masyarakat (PNPM) or National Program of Community Development in Rural and Urban and other similar programs. Even recently the President through the Ministry of National Education and Culture launched the President's Scholarship for students from class poor. 
These programs were admittedly contributes not a little early for community empowerment and is expected to break the chain of poverty in this country. Variety of the program has not yet touched all the interests and aspirations of the poor that should deserve special attention and should be given priority. This kind of centralistic perspective and perception was still continued by modern Indonesian government, at least until New Order Government (1988) which benefited Java as the center of Indonesian politic and economy (Sulistiyono, 2003; Sulistiyono and Rochwulaningsih, 2014). the poverty alleviation program weaknesses are still oriented towards economic growth and less touches on the equity also because the nature of programs that tend to caricature than transformative. The target to be achieved more emphasis on charity rather than productivity and creativity. Based on the research results Santosa, et al ., ( 2006) ; Santosa , et al ., ( 2007), Santosa and Priyono (2008) revealed that the inaction of various community development programs achieve goals in various rural areas due to several internal and external factors. Some of the factors is listed in Figure 1.

According to Hamid ( 2013) in addition to

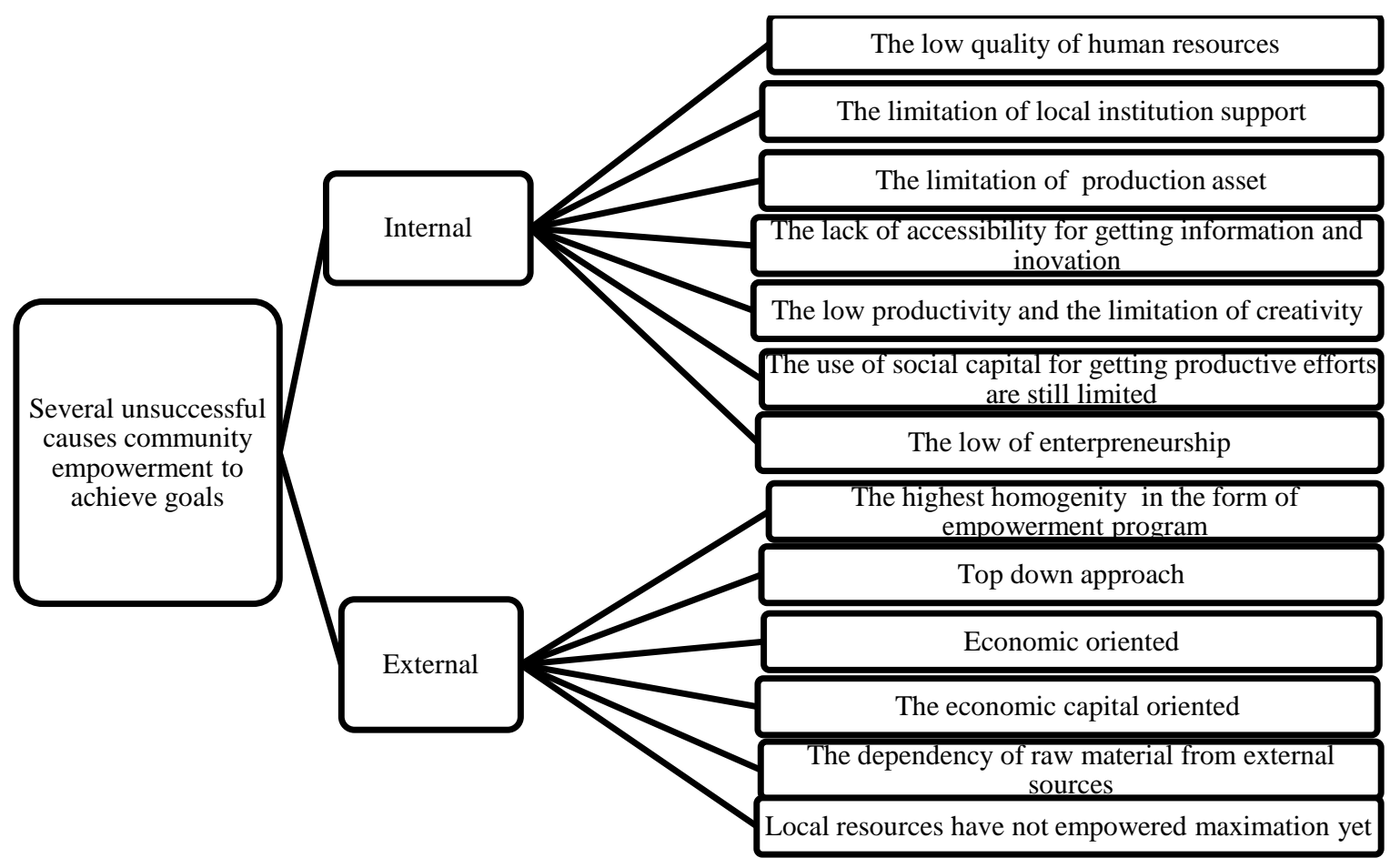

Figure 1. Several Unsuccessful Causes Community Empowerment to Achieve Goals (Santosa, et al,2006; Santosa, et.al 2007, Santosa and Priyono, 2008)

The issue is how the poverty reduction strategy and the factors that cause the condition observed in Figure 1? According to the author, one effective solution, namely: developing a model of strategic management empowerment based on local resources. The development of strategic management models associated with the development of rural communities that take into account the suitability of the mission, objectives, strategies and tactics with the scope of the problems that occur.

In much cases, political approach is stronger than management in every step of the optimization of the formulation of policies. 
Moreover, political struggle often resulted in a zero sum game pattern and always bring up the losing team and the winning team. The group that makes the rules wins and the losing team must be willing to "willing" to be ruled. In this regard, in the perspective of strategic management of each asset that is inclusive of all potential of human resources, natural resources, economic resources (capital), social and cultural resources to be functioned as an energy source. Strengthening the autonomy and independence of the wider village community for all people to manage local resources need to be intensified. Therefore, management empowerment in principle is a continuum process and involve the active participation of all elements of society.

Empowerment is not the instant process, but it is a process of transformation that needed a series of stages in order intended of social change not deviated from the early goal. The early step and crucial thing is to identify the problem roots that effected to rural poverty problems, such as: (1) the instability for utilizing natural resources, (2) the lack of economic assets, and (3) the low quality of human resources. As its consequences, social transformation is still low and the poor.

In much cases, political approach is stronger than management in every step of the optimization of the formulation of policies. The group that makes the rules wins and the losing team must be willing to "willing" to be ruled. In this regard, in the perspective of strategic management of each asset that is inclusive of all potential human resources, natural resources, economic resources (capital), social and cultural resources to function as an energy source . Strengthening the autonomy and independence of the wider village community for all people to manage local resources need to be intensified .Therefore , management empowerment in principle is a continuum process and involve the active participation of all elements of society .

$$
\text { Design formulation of strategic }
$$
management of rural community development based on local resources takes rational reasoning in modify between goal and the positive real needs and community problems. The crucial problem of strategic management of rural community empowerment are social planner inability in identify the positive real needs. It means that community aspiration and the real needs, in much cases, did not match with the policy which is arranged by the government authority. The research's result showed that empowerment through formulation and implementation of effective strategic management are able to effect work effectivity (Craig and Grant, 1993). The successful of strategic management of rural community development based on local resources can be indicated from indicators are in the following, such as attached in Figure 2.

In a practical level, the formulation of community development is viewed fromstrategic management based on local resources that integrate with decision makers to implement policies for pro-poor policies still need to be transformed in order to make the various stakeholders would be ready. Term is taken from the word transform which is defined as the change (Neufbet and Guralnik, 1988), and the transformation is defined as a process of change. More broadly viewed as a process of transformation changes the shape, structure and characteristics and the ability of the system to be able to grow and nourish the social life of the community through socio- cultural reform (Pranaji, 1999). 


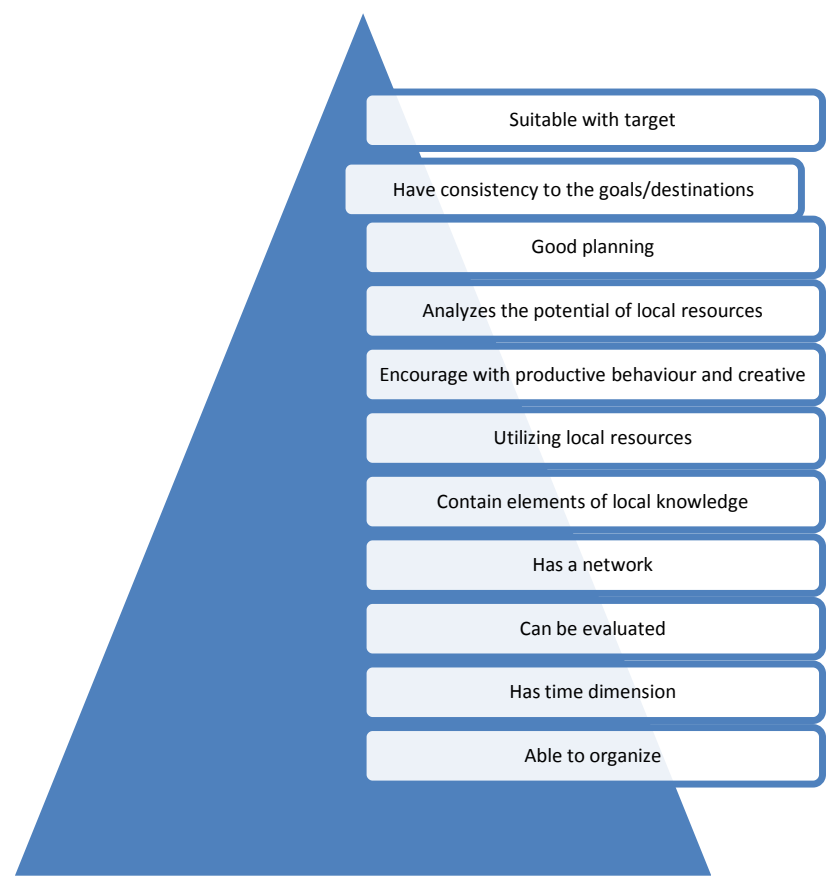

Figure 2. Some indicators of the success of strategic management community development based on local resources.

It should be recognized that such government programs bring great benefits to the poor, but based on observations for more than 20 years of working in community development , either through field research and community service in the process of social transformation has still much home work left by the organizers of the development both at policy level and in practical terms , namely : aspects of risk management, damage to the environment and culture shock (in it including massive social conflict) often escape the attention of the stakeholders. We usually care after the incident occurred. We give much comments, but when an accident have not yet occurred we did not do anything and exit without notification as if all of it just merely ritualistic.

\section{Conclusion}

According to the analysis above, it can be concluded are as follows:
(1) Strategic management can encourage the empowerment of social transformation towards an appropriate way to outline strategies that have been implemented without losing flexibility, all the policy makers can synergize all related elements. But if the opposite happens then it will be possible occurrence of mismanagement and the emergence of various risks empowerment.

(2) There is still founded weaknesses synergy of all stakeholders and that makes politics as commander and they become perpetrators of political policies, but less to think about and implement community empowerment.

(3) There is still discovered policy as homework for policy makers and often out of count from the planning and implementation, namely : risk management, environmental management and resolution of conflicts. It is often occur when policies that have been made make the natural resources to be over exploited. 


\section{Suggestions}

(1) Its recommended to policy makers and all stakeholders in order to synergize all local resources, both natural and human resources, reduce chances of environmental damage, social conflict and various other development risks as "good side effect" of the empowerment of rural communities.

(2) Readiness for all stakeholders to not only be a political actor, but rather emphasizes the empowerment of community as a whole to work together to realize the mutual pro-poor policies.

(3) Risk factors can be anticipated and mitigated early on when entering the risk management policy of community empowerment.

\section{References}

1) Central Bereau of Statistics. (2013). Jakarta: Indonesia Dalam Angka

2) Craig, James. C and Robert M. Grant. (1993). Strategic Management. Jakarta: PT Elex Media Computindo

3) Friedmann, John. (1992). The Politic of Alternative Development. Cambridge: Cambridge Blackwell Publisher

4) Hamid, Edi Suandi. (2013). Kemiskinan di Indonesia: Potret Jatuhnya Kehidupan Ideal Masyarakat Madani dan Lestari.Proceedings of the 2013 National Seminar on Toward Civil Society and Sustainability, 1-14

5) Santosa, Imam, Jarot Santoso and Slamet Rosyadi. (2006). Model Pengembangan Perilaku Petani Tepian Hutan dalam Pengelolaan Hutan Sebagai Cadangan Pangan. Research Report of RUKK Program, Jakarta: Ministry of Research and Technology, $38-40$
6) Santosa, Imam and Rawuh Edy Priyono. (2007). Farmer Group Empowering Through Increasing Market Accessibility and Local Wisdom Utility. Research Report of Collaboration between Tokyo University and Jenderal Soedirman University (unpublished). Purwokerto, 10-15

7) Santosa, Imamand Rawuh Edy Priyono. (2008). Rural Community Empowerment Through Local Resources Management of Agrotourism-Based Environmentally Friendly. Research Report of The 2008 of Grant Competence (The first year). Directorate of Higher Education. Jakarta: Ministry of Education and Culture. Jakarta, 42-43

8) Santosa, Imam, and Rawuh Edy Priyono. (2009). Rural Community Empowerment Through Local Resources Management of Agrotourism-Based Environmentally Friendly. Research Report of The 2009 of Grant Competence (The Second year). Jakarta: Directorate of Higher Education. Ministry of Education and Culture, 44-45

9) Sulistiyono, Singgih Tri. (2003). The Java Sea Network: Patterns in the development of Interregional Shipping and Trade and Process of National Economic Integration In Indonesia. PhD's Dissertation in Leiden University.

10)Sulistiono, Singgih Tri. and Yetty Rochwulaningsih. (2014). Contest For Hegemony: Dynamic of Inland and Maritime Culture Relations In The History of Java Island Indonesia. Journal of Marine and Island Culture,3 (2), 125-126

11) Wrihatnolo, Randy $R$ and Riant Nugroho Dwidjowijoto. (2002). Manajemen Pemberdayaan. Jakarta: PT Elex Media Computindo 